\title{
Development of coverage and its evaluation in the treatment of chronic wounds
}

\author{
Marcia Diana Umebayashi Zanoti ${ }^{1}$ \\ Helena Megumi Sonobe ${ }^{2}$ \\ Sidney José Lima Ribeiro ${ }^{3}$ \\ Ana Maria Minarelli Gaspar ${ }^{4}$
}

\section{Development of coverage and its evaluation in the treatment of chronic wounds}

Objective. To describe the development of the bacterial cellulose coating with anti-inflammatory Ibuprofen (BC/ $\mathrm{Ibu}$ ) and to evaluate the cicatrization process with its use in patients with chronic wounds of venous and diabetic etiology. Methods. Longitudinal descriptive study. The cellulose membrane, cultivated with bacteria Gluconacetobacter xylinus and with incorporation of Ibuprofen, was used in the treatment of patients with chronic wounds in public health services in a Brazilian municipality. The ideal coverage characteristics were evaluated through physical, chemical and cell proliferation tests. Results. The sample consisted of 14 patients ( 10 women and 4 men), 8 with venous ulcer, 5 with diabetic foot and one with mixed wound. There was reduction of area and pain in 9 lesions; total healing of 3 wounds; and debridement of the devitalized tissue in 5 wounds with increased area. The use of the membrane was important in the reduction of pain, exudation and ease in the accomplishment of the curative. Conclusion. $\mathrm{BC} / \mathrm{lbu}$ favored the cicatrization process of patients with chronic vasculogenic wounds.

Descriptors: diabetic foot; varicose ulcer; cellulose; ibuprofen;wound healing; Gluconacetobacter xylinus.

\section{Desarrollo de cobertura y su evaluación en el tratamiento de las heridas crónicas}

Objetivo. Describir el desarrollo de la cobertura de celulosa bacteriana con antiinflamatorio Ibuprofeno (CB/ Ibu) y evaluar el proceso de cicatrización en la utilización en pacientes con heridas crónicas de etiología venosa y diabética. Métodos. Estudio descriptivo Iongitudinal. La membrana de celulosa, cultivada con bacterias Gluconacetobacter xylinus y con incorporación del Ibuprofeno se utilizó en el tratamiento de pacientes con heridas crónicas en servicios de atención pública de un municipio brasileño. Se evaluaron características de cobertura ideal mediante pruebas físicas, químicas

1 Nurse, Ph.D student. Paulista State University "Júlio de Mesquita Filho" (UNESP), Araraquara-SP, Brazil. email: ma.zanoti@bol.com.br

2 Nurse, Ph.D. Professor, University of São Paulo, Ribeirão Preto-SP, Brazil. email: megumi@eerp.usp.br

3 Chemist, Ph.D. Titular Professor, UNESP, Araraquara-SP, Brazil. email: sidney@iq.unesp.br

4 Odontologist, Doctor. Associate Professor, UNESP, Araraquara-SP, Brazil. email: anamaria@foar.unesp.br

Conflict of interest: None.

Funding: CAPES.

Received: May 31st 2017.

Accepted: August 30th 2017.

How to cite this article: Zanoti MDU, Sonobe HM, Ribeiro SJL, Gaspar AMM. Development of coverage and its evaluation in the treatment of chronic wounds. Invest. Educ. Enferm. 2017; 35(3): 330-339

DOI: 10.17533 /udea.iee.v35n3a09 
y de proliferación celular. Resultados. La muestra fue constituida por 14 pacientes (10 mujeres y 4 hombres): 8 con úlcera venosa, 5 con pie diabético y uno con herida mixta. Se redujo el área y el dolor en 9 lesiones; la cicatrización total de 3 heridas; y el debridamiento del tejido desvitalizado en 5 heridas con aumento del área. El uso de la membrana de celulosa disminuyó el dolor de la exudación y facilitó la realización del vendaje. Conclusión. La CB/lbu favoreció el proceso de cicatrización de los pacientes con heridas crónicas vasculogénicas.

Descriptores: pie diabético; úlcera varicosa; celulosa; Ibuprofeno; cicatrización de heridas; Gluconacetobacter xylinus.

\section{Desenvolvimento de cobertura e sua avaliação no tratamento de feridas crônicas}

Objetivo. Descrever o desenvolvimento da cobertura de celulose bacteriana com anti-inflamatório Ibuprofeno (CB/lbu) e avaliar o processo de cicatrização com a

\section{Introduction}

Assistance to the wounded person involves aspects such as types of injuries or traumas, with their respective specificities; however, it is necessary to evaluate the patient in the different sociocultural and health care contexts to which they are inserted, identifying the characteristics of each wound. Through integral analysis it is possible to plan the nursing care and the multi professional team to solve the demand of the patients. ${ }^{(1)}$

Chronic wounds result from absences from the ordered and temporal tissue repair process or from anatomical and functional restoration. (2) Among the chronic wounds we work with vascular wounds, venous ulcer (VU) and diabetic foot (DF) lesions, because they constitute a major public health problem, both in Brazil as in the world, with physiological, psychosocial and cultural repercussions. ${ }^{(2)}$

Treatment involves several factors and may be difficult, due to the disease's own changes, such as sua utilização em pacientes com feridas crônicas de etiologia venosa e diabética. Métodos. Estudo descritivo longitudinal. A membrana de celulose, cultivada com bactérias Gluconacetobacter xylinus e com incorporação do Ibuprofeno, foi utilizada no tratamento de pacientes com feridas crônicas em serviços de atendimento público de um município brasileiro. Foram avaliadas as características de cobertura ideal mediante testes físicos, químicos e de proliferação celular. Resultados. A amostra foi constituída por 14 pacientes ( 10 mulheres e 4 homens), sendo $8 \mathrm{com}$ úlcera venosa, $5 \mathrm{com}$ pé diabético e um com ferida mista. Houve redução da área e da dor em 9 lesões; cicatrização total de 3 feridas; e o debridamento do tecido desvitalizado em 5 feridas com aumento da área. $\mathrm{O}$ uso da membrana além da diminuição da dor, da exsudação e facilidade na realização do curativo. Conclusão. A CB/lbu favoreceu o processo cicatrização dos pacientes com feridas crônicas vasculogênicas.

Descritores: pé diabético; úlcera varicosa; celulose; ibuprofeno; cicatrização; Gluconacetobacter xylinus.

associated comorbidities, advanced age, eczema and dermatosclerosis, ${ }^{(3)}$ and the therapy is related to correction of the preexisting condition and use of local measures to occur. ${ }^{(4)}$ Among the various coverage's used in the treatment are activated carbon, charcoal with silver salts for lesions with a large amount of exudate; hydrocolloids in small and medium lesions; antibiotics and collagenase. ${ }^{(5)}$

Topical administration drugs have been frequently indicated, because they exert an adjacent peripheral effect, ${ }^{(6)}$ and among nonsteroidal antiinflammatory drug in clinical practice we have ibuprofen. Its mechanism of action is the inhibition of the cyclooxygenase type 1 and 2, reducing the synthesis of prostaglandins and the sensitization of peripheral nerve endings, common site of pain and inflammation. Its topical administration promotes therapeutic concentration in the target tissue, however the serum level does not generates adverse reaction. ${ }^{(6)}$ On the other hand, Ibuprofen is almost soluble in water and easily solubilized in alcohol, acetone, ether and methylene chloride. ${ }^{(7)}$ 
The objective of this research was to describe the development of bacterial cellulose coverage with anti-inflammatory Ibuprofen (BC/lbu) and to evaluate the cicatrization process with its use in the treatment of chronic wounds, of venous and diabetic etiology of lower limbs, of patients in clinical follow-up in public assistance services in a Brazilian municipality.

\section{Methods}

This work was developed as a doctoral thesis of the Institute of Chemistry, Biotechnology Program of UNESP of Araraquara-SP, from March 2013 to February 2017, BC blankets were prepared in the Laboratory of Photonic Materials of the Institute of Chemistry of the UNESP, whose cultivation of the bacteria Gluconacetobacter xylinus occurred in 72 hours at $28^{\circ} \mathrm{C}$, in static culture medium.

For the removal of the bacteria, the membrane was treated with a dilute solution of sodium hydroxide at $80^{\circ} \mathrm{C}$ for 20 minutes, followed by thorough washing with distilled water. After this preparation, the $\mathrm{BC}$ blankets were immersed in the anti-inflammatory Ibuprofen, which was diluted with $1 \mathrm{ml}$ of distilled water at the concentration of $0.5 \mathrm{mg} / \mathrm{cm}^{2}$ and placed in an oven at $28^{\circ} \mathrm{C}$ for 24 hours. These membranes were also analyzed and characterized by means of different physical tests, such as Scanning Electron Microscopy (SEM), $\mathrm{X}$-ray diffraction, Thermogravimetric Analysis (TGA), Differential Scanning Calorimetry (DSC), Infrared, UV-Visible Spectroscopy (UV-vis) and cell proliferation.

After drying, BC/lbu membranes were packed in surgical grade paper and sterilized by gamma rays by Embrarad, Cotia (SP). The BC/lbu coverage was applied in a non-probabilistic sample, for convenience, of patients in clinical follow-up in the public assistance services of a Brazilian municipality. The project was approved by the Research Ethics Committee through the CAAE registry: 36527414.7.0000.5512, and with report number: 911.647. Participants were requested to authorize the photographic registry of the evolution of the wound using the $\mathrm{BC} / \mathrm{lbu}$ coverage. Ulcers evaluation was performed with the photographic images of a digital camera (Sony Cyber-shot 14.1 mega pixels), and the analysis of its total area was measured with ImageJ 1.46 software, in the public domain. Thus, the areas of each ulcer were calculated by ImageJ software, with the definition of ulcer healing index (UHI), where UHI-1, total re-epithelization; UHI-O without signs of re-epithelialization; $0<\mathrm{UHI}<1$ reduction of the ulcerated area; $\mathrm{UHI}<0$-increase of ulcerated area, calculated by the formula: initial area minus the final area, divided by the initial area.

A quantitative, longitudinal descriptive study was carried out involving individuals of both sexes, over 18 years of age, who had chronic wounds of vasculogenic etiology, VU and/or DF, at any stage of cicatrization, in the chronic phase of the wound, attending the care services of a Brazilian municipality; were excluded from the study, patients who were not carriers of vasculogenic wounds or who were not in the chronic phase. Treatment was discontinued after full healing or at most 120 days or when the patient changed the conduct by medical request or by his or her will.

The dressings of the enlightened patients were performed by them and supervised by the researcher, after training and the others the researcher herself performed daily in the health units and/or in their homes. This wound was evaluated on the first day of treatment and weekly, by measuring the total area through photographic records, and the patient was the control. Pain was assessed weekly through the pain intensity scale.

After, the data were analyzed statistically (mean, median, percentage) and the areas of wounds with Image J software 1.46.

\section{Results}

The BC/lbu membranes, using the physicochemical techniques of SEM, X-ray diffraction, TGA, DSC, Infrared, UV-vis, cell proliferation assays with cultured fibroblasts, as well as the release tests of Ibuprofen and tests of permeation and retention of 
Ibuprofen, presented all the necessary properties and absence of adverse reactions, which are characteristics of an ideal coverage.

Among the 14 participants that constituted the sample of this study, $8(57.10 \%)$ had VU, 5 (35.70\%) DF and 1 (7.20\%) mixed ulcer, 2,483 days is the average time of existence of the wound, representing 6.8 years; 47,30 days was the average of the treatment, from all 17 wounds, $9(52.94 \%)$ had area reduction, 3 (17.65\%) total healing and 5 (29.41\%) debridement with increased area (Table 1).

The study sample consisted of 14 patients, of which 10 (71.50\%) were female and 4 (28.50\%) were male. The participants' ages ranged from
43 to 86 years, with a mean of 64.7 years and a median of 53 years. As for marital status 6 (43.0\%) were married, 4 (28.60\%) were widowed, $2(14.20 \%)$ were single and $2(14.20 \%)$ were divorced. In relation to schooling, 2 (14.30\%) were illiterate; 7 (50.0\%) studied a number of years that are currently classified as fundamental I; 1 (7.10\%) fundamental II; and 4 (28.60\%) high school. As for comorbidities, 10 (71.43\%) patients were diabetic and hypertensive, 3 (21.43\%) hypertensive and 1 (7.14\%) were diabetic only. About the income of studied participants, 11 (78.57\%) were excluded due to health problems or retirees with an average of one to two minimum wages, 2 (14.29\%) had no income, depending on the family and 1 (7.14\%) worked without a portfolio signed, receiving less than one minimum wage.

Table 1. Characterization of the wound, according to type, time of existence and treatment with $\mathrm{BC} / \mathrm{Ibu}$ and dimensions of the initial and final areas, during the domiciliary follow-up of the sample studied

\begin{tabular}{|c|c|c|c|c|c|c|c|}
\hline Patient & $\begin{array}{l}\text { Wound } \\
\text { type }\end{array}$ & $\begin{array}{l}\text { Time of } \\
\text { existence }\end{array}$ & $\begin{array}{l}\text { Time of } \\
\text { treatment } \\
\text { (days) }\end{array}$ & $\begin{array}{l}\text { Initial } \\
\text { areal } \\
\left(\mathrm{cm}^{2}\right)\end{array}$ & $\begin{array}{c}\text { Final area } \\
\left(\mathrm{cm}^{2}\right)\end{array}$ & *IUA & $\begin{array}{c}\text { Reduction } \\
\%\end{array}$ \\
\hline 1 & VU & 10 years & 120 & 4.93 & 2.07 & 0.57 & 57.90 \\
\hline 2 & Vu & 20 years & 48 & 44.62 & 29.8 & 0.33 & 33.07 \\
\hline 3 & DF & 2 years & 20 & 7.29 & 6.16 & 0.15 & 15.47 \\
\hline 4 & VU & 1 year & 120 & 7.41 & 6.78 & 0.08 & 8.48 \\
\hline 5 & DF & 21 days & 28 & 0.79 & 0 & 1 & 100 \\
\hline 6 & DF & 1 year & 28 & 4.25 & 2.78 & 0.34 & 34.45 \\
\hline 7 & VU & $\begin{array}{l}1 \text { year } 9 \\
\text { months }\end{array}$ & 38 & 18.44 & 14.51 & 0.29 & 29.31 \\
\hline 8 & VU & $\begin{array}{l}1 \text { year } 6 \\
\text { months }\end{array}$ & 15 & 6.44 & 8.52 & -0.32 & $32.25^{*}$ \\
\hline 9 & MU & 7 years & 36 & 33.49 & 30.86 & 0.07 & 7.86 \\
\hline 10 & Vu & 10 years & 120 & 8.70 & 22.59 & -1.60 & $159.50 *$ \\
\hline $11 a$ & VU & 40 years & 15 & 2.09 & 1.98 & 0.05 & 5.21 \\
\hline $11 \mathrm{~b}$ & & & & 0.86 & 1.29 & -0.49 & $49.49 *$ \\
\hline $11 \mathrm{c}$ & & & & 5.44 & 9.04 & -0.66 & $66.09 *$ \\
\hline 12 & Vu & 5 months & 35 & 2.94 & 4.52 & -0.53 & $53.77^{*}$ \\
\hline 13 & DF & 6 months & 15 & 15.32 & 13.58 & 0.11 & 11.37 \\
\hline $14 a$ & DF & 10 days & 14 & 1.13 & 0 & 1 & 100 \\
\hline $14 b$ & & & 10 & 1.82 & 0 & 1 & 100 \\
\hline
\end{tabular}

(*) Increase of the ulcered area 
We present the descriptive evolution of the participants during the follow-up of this study.

Participant 1. Female, 59 years, medical diagnosis of Diabetes mellitus, (DM) systemic arterial hypertension, hypothyroidism and VU, wound with 10 years of existence, that at the beginning of the treatment, with the presence of a large amount of serous exudate, at the end of the 120-day treatment, there was a $57.90 \%$ decrease in the area, absence of exudate, odor and pain, ease of coverage applicability and dressing permanence.

Participant 2. Female, 57 years, medical diagnosis of DM, systemic arterial hypertension and VU. The wound's lifetime was 20 years. At the beginning of the treatment there was a large serous exudation, with a foul odor, presence of slough and intense pain. At the end of 50 days of treatment, there was worsening of the clinical picture, with hyperthermia, intense pain in the leg and the participant's request for interruption of $\mathrm{BC} /$ Ibu treatment, the area was reduced by $33.07 \%$. When $\mathrm{BC} / \mathrm{lbu}$ treatment was discontinued, the patient reported ease of coverage, but complained of severe pain.

Participant 3. Man, 65 years, medical diagnosis of DM, systemic arterial hypertension and DF, with 2-year wound life after 2-finger amputation (due to diabetes complications). Initially at the treatment, the wound had a large amount of purulent exudation. After 20 days of $\mathrm{BC} / \mathrm{lbu}$ treatment, there was a $15.47 \%$ decrease in area and exudation, besides the debridement of slough at the peripheral border, with granulation tissue. However, the participant requested a discontinuation of treatment claiming that he was not noticing improvement.

Participant 4. Man, 65 years, medical diagnosis of DM, systemic arterial hypertension and VU, with time of existence of the wound, of about 1 year. At the beginning of the treatment there was a mean amount of serous exudation and mild pain. At the end of BC/lbu treatment at 120 days, the area of the wound was $8.48 \%$ smaller, with no exudation, odor and satisfaction report due to the absence of pain, ease of application of this cover and maintenance of the dressing without extravasation.

Participant 5. A 86-year-old woman, a medical diagnosis of DM, systemic arterial hypertension and DF, had been injured 20 days due to the use of a slipper whose rubber handle was replaced by a piece of wire. In the initial evaluation of the wound there was presence of small amount of exudation and pain, from moderate to intense. With 28 days of treatment, there was total re-epithelialization, and the same one reported absence of pain, ease in the application of the cover and happiness for healing of the wound in a short time.

Participant 6. Man, 57 years, medical diagnosis of DM, systemic arterial hypertension and DF, with wound of one (1) year. Initially at treatment, there was a large amount of serous exudate. After 28 days of treatment, when the area of the wound was reduced by $34.45 \%$, there was no exudate; however, it started a hyperthermia and malaise, which resulted in hospitalization and surgical approach to the wound. When our follow-up was interrupted, the patient reported absence of pain, ease of coverage and dressing.

Participant 7. Female, 63 years, medical diagnosis of DM, systemic arterial hypertension and VU, the first wound occurred more than 30 years ago, with no apparent cause; the current wound was 1 year and 9 months. The wound had a mean amount of serous exudation, local hyperemia and edema, and a large amount of slough throughout the wound; reported a lot of local pain and in the lower left limb. The treatment was interrupted at 38 days, when a reduction of the wound area of $29.31 \%$, granulation tissue growth throughout the wound was reported at the time of application of the cover, but improvement soon afterwards, absence of use of analgesic via oral, besides the ease in the application of the cover and dressing, without extravasation of exudate.

Participant 8. Female, 43 years, medical diagnosis of systemic arterial hypertension, hypothyroidism and VU, 1 and half years ago. At the beginning there was presence of a medium 
amount of serosanguinolent exudation in the wound, odor, and presence of necrotic tissue in the crust (eschar). After 15 days of treatment, at the vascular return medical visit, there was an exposure of the entire wound bed, with a $32.25 \%$ increase, due to the total debridement of necrotic and devitalized tissue (eschar), with total exposition of the wound area, which corresponds to the important phase of the scarring process and not lack of improvement. When treatment was interrupted, was related pain relief, ease of coverage, dressing without exudate and odor extravasation, and improvement in wound appearance due to debridement of the necrotic area were reported (Figure 1 ).

Participant 9. Female, 63 years, medical diagnosis of DM, systemic arterial hypertension and mixed ulcer (MU) for 7 years, with presence of large amount of serosanguinolent exudation and slough over the entire border of the wound, absence of wound bed, in addition to reports of intense pain, took painkillers several times a day. After 37 days of treatment, it was observed a decrease of the wound area of $7.86 \%$ and absence of exudate. However, it was diagnosed that MU and not only venous and treatment was discontinued, but the same reported significant improvement of pain, ease in the application of the coverage.

Participant 10. Woman, 84 years, aphasic after stroke, medical diagnosis of systemic arterial hypertension and VU from 10 years ago, which arose after an angioplasty. Wound with medium amount of serosanguinolent exudation and intense pain report. After 120 days, the area increased by $159.50 \%$, due to the debridement of slough over the entire border of the wound and the growth of granulation tissue throughout the wound bed with a decrease in depth. At the end of $\mathrm{BC} / \mathrm{lbu}$ treatment, the son reported significant pain improvement, since she took daily pain medication and reduced the frequency to one analgesic every 3 days, ease in the application of the cover and dressing, without extravasation of exudate in the curative.

Participant 11. Man, 66 years, medical diagnosis of DM, systemic arterial hypertension and VU from
40 years ago, after a car accident, with two fractures in his leg. At the beginning of the treatment, the patient had a large amount of serosanguinolent exudation, in addition to peripheral hyperemia throughout the extension of the median portion inferior to the right knee; lower limb edema and three (3) wounds, two in the right leg and one in the left leg. After 15 days of treatment, it was interrupted at the request of the patient. In relation to the wounds, there was a decrease in the area of the wound in the left leg of $5.21 \%$ and increase in the other two of the right leg, one in $49.49 \%$ and another in $66.09 \%$, due to the debridement and absence of slough throughout edge and wound bed. Besides, there was total absence of edema in the lower limbs and pain. When the treatment was interrupted, the participant reported absence of pain, ease in the application of the cover, without extravasation of exudate.

Participant 12. Female, 62 years, medical diagnosis of systemic arterial hypertension, obesity and VU for 5 months, with presence of small amount of serous exudation, slough throughout the wound, edema $(++/++++)$ and reports of much pain. After 35 days, the treatment was interrupted at the request of the participant; there was a $53.57 \%$ increase in area due to total debridement of the slough, besides the regression of the edema in the left lower limb. Despite the persistence of pain, it was identified ease in the application and handling of the cover and absence of extravasation of exudate in the dressing.

Participant 13. Female, 56 years old, housekeeping, medical diagnosis of DM and DF from 6 months, with a large amount of serous exudation, reports of constant pain and worsening during the dressing procedure. After 15 days of treatment there was a decrease in the area of the wound of $11.37 \%$, of the serous exudation and improvement of pain after dressing. Despite these results, the nursing professional modified the coverage used in the dressing. Thus, when the treatment was interrupted, persistence of pain during dressing was reported, but it improved after the end, ease in the application of the cover and absence of extravasation of exudate in the dressing. 
Participant 14. Woman, 80 years, medical diagnosis of DM, systemic arterial hypertension and DF from 10 days. At initial evaluation, there was little serous exudation, thin and fragile skin around. At the end of 14 days of treatment with $\mathrm{BC} / \mathrm{lbu}$, in the left foot there was a 100\% decrease in area and in the right foot there was a decrease of $100 \%$ in 10 days. Absence of pain, ease of application and coverage management, and absence of exudate and odor extravasation have been reported (Figure 2).
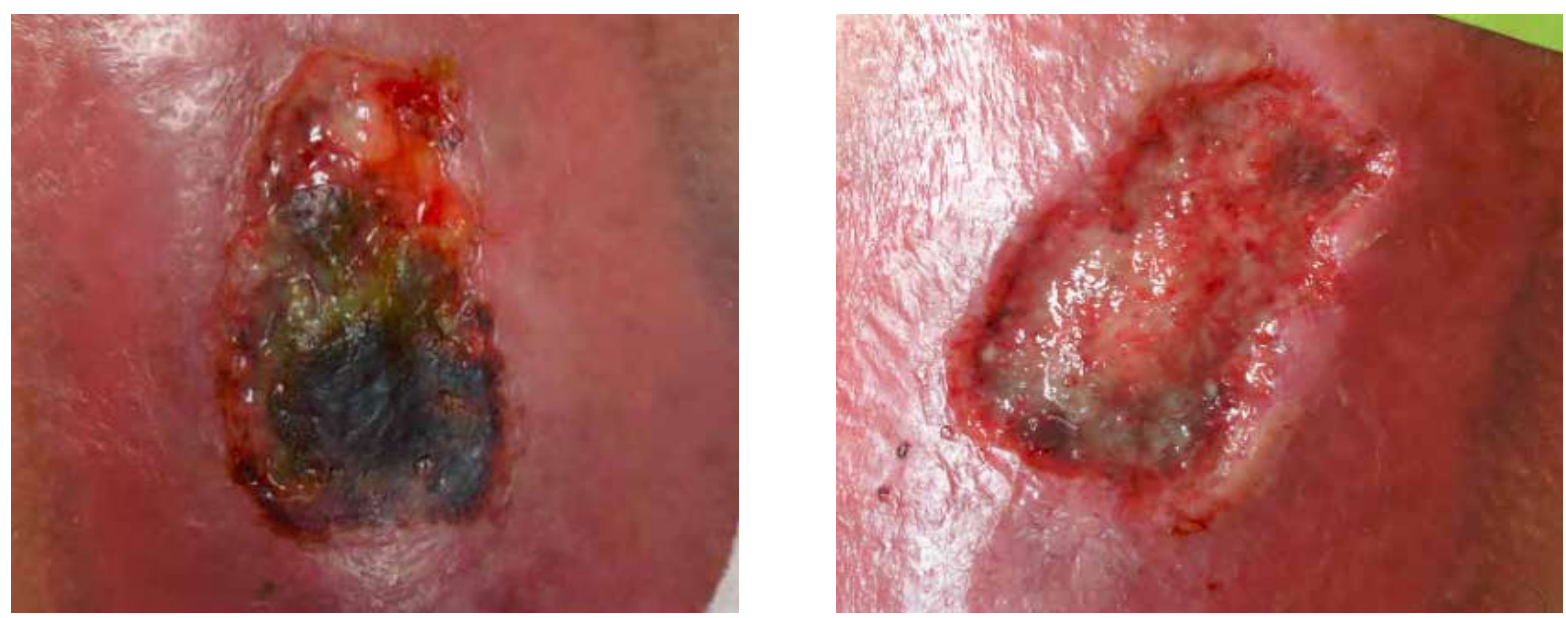

Figure 1. Photo of the first and last day of the coverage application of $\mathrm{BC} / \mathrm{lbu}$
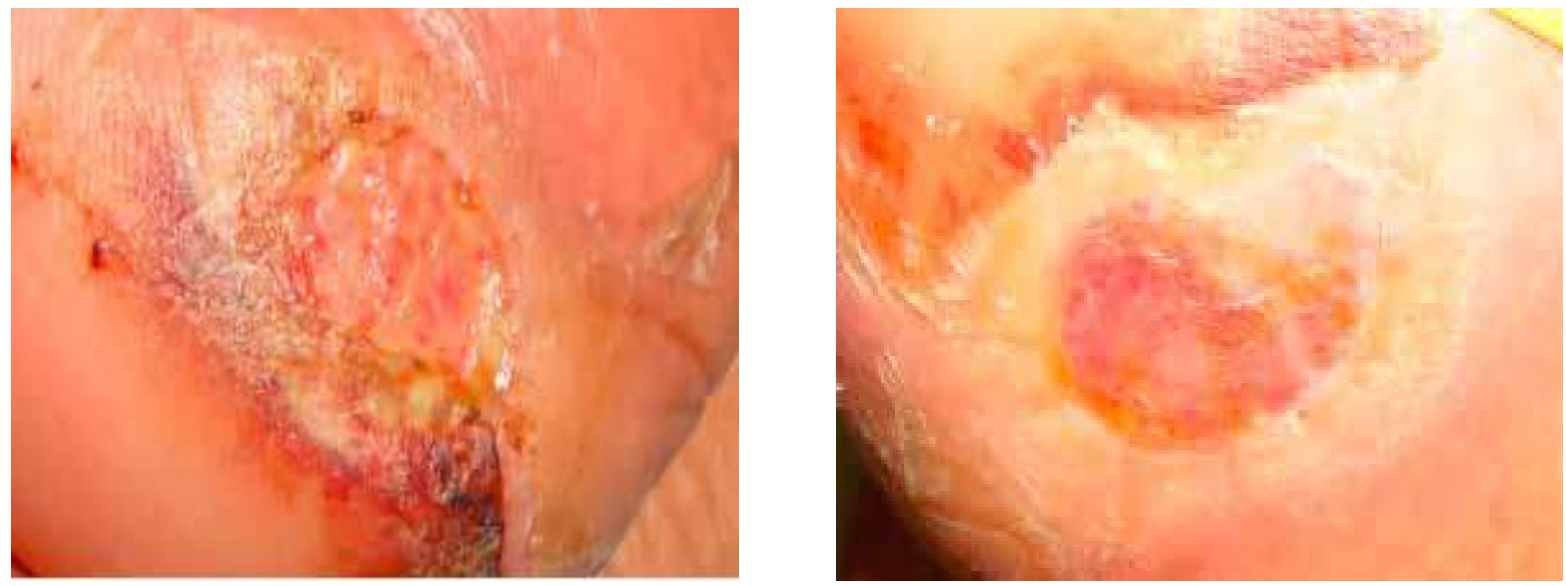

Figure 2. Photo of the first and last day of the coverage application of $\mathrm{BC} / \mathrm{lbu}$

\section{Discussion}

The predominance of these wounds in females is usually related to female hormones and gestation, since hormonal changes predispose to chronic venous insufficiency and, consequently, to VU formation. Data reported in the literature indicate a 2.3 fold higher proportion of vascular wounds in women than in men. ${ }^{(8-10)}$ Regarding age, data found in a study ${ }^{(11)}$ in the city of Niterói, showed an average of 63.5 years, the same data found in this study. Schooling is a fundamental element so that people can access and seek information 
in general, in addition to providing a better understanding of the guidelines given by the health professional. Similar data were found in another study, where low level of schooling limited access to information, making it difficult to understand the diet, physical activity, medication dosage, among other factors. ${ }^{(12)}$

The process of wound healing depends on a multiplicity of factors, related to the physiological, social aspects, accessibility of the health care and feeding system, among others. Therefore, for the analysis of the sample profile of this study, we used the concept of Social Determinants of Health $(\mathrm{SDH})$, that the living and working conditions of individuals and population groups, related to their health situation. ${ }^{(13,14)}$ Thus, when analyzing sociodemographic and clinical data, considering SDH from the perspective of the National Commission on Social Determinants of Health, which expands the discussion in greater detail on social, economic, cultural, ethnic/racial, psychological and behavioral factors. ${ }^{(13,14)}$ In this study, the specificity refers to the indication of coverage and the performance of the curative intervention. It is important to note that the Human Development Index (HDI) measures the level of human development in the countries using as indicators of education (literacy and enrollment), longevity (life expectancy at birth) and income (GDP per capita). Countries with HDI of up to 0.499 have low human development; countries with indices between 0.500 and 0.799 are considered medium human development and countries with $\mathrm{HDI}$ higher than 0.800 have high human development. ${ }^{(15)}$

The research was carried out in the municipality of the interior of São Paulo, in Araraquara, whose $\mathrm{HDI}$ is 0.815, which indicates a high human development. However, the profile of our sample does not corroborate this $\mathrm{HDI}$, since we have from illiterate patients, with a family income of a minimum wage and with hopeless life, for having health problems for years and with a wound that does not heal. These considerations may help to understand the difficulties to manage the factors in the sample of this study, which influenced the occurrence of health problems and risks for possible complications in people with vasculogenic wounds, as well as in the evaluation of $\mathrm{BC} / \mathrm{lbu}$ use. Among these, we identified the age, comorbidities, temporality of wound existence, use of oral medications with several active principles, as well as family income, access to formal study, employment relationship, which interfere in the onset or maintenance of an injury.

From the clinical point of view, the participants in this study had a predominance of DM and systemic arterial hypertension, and the vasculogenic wound, whether DF or VU, are the complications of these diagnoses, which further compromises the scarring process. We also point out that the temporality of the lesion varied between 10 days and 40 years, with a history of failures of other therapies, mainly the topical ones, with use with different medications. In addition, we observed that these individuals had no possibility of adequate maintenance of food, hygiene and effective daily dressing, as well as presenting difficulties for total adherence to treatment.

The nutritional condition is another decisive factor in the evolution of the scarring process due to the specificity of action as the proteins favor the inflammatory response and the synthesis of collagen with the remodeling of the ulcer; carbohydrates and fats by providing energy; vitamin $\mathrm{K}$ by acting in the coagulation process, $B$ complex in collagen metabolism, zinc in cell proliferation and epithelization; and manganese, copper, magnesium and vitamins $A$ and $C$ as contributing to the synthesis of collagen. ${ }^{(16,17)}$ Thus, these nutritional factors could explain the fact that the participants present ulcers with greater difficulty in healing (P8, P10, P11 and P12), as they reported eat predominantly carbohydrate and frying, which is not adequate considering that almost all have other comorbidities such as DM or systemic arterial hypertension. On the other hand, the increased area of the wounds of these individuals may be related to the fact that $\mathrm{BC} /$ Ibu presents the characteristics of an ideal cover, maintaining the moisture in the wound bed, which favors the occurrence of the healing process, process control inflammatory, as well as natural debridement, according to results of the analysis 
of the chemical and biochemical characteristics of this study.

The appearance of chronic wounds, especially DF and $\mathrm{VU}$, interferes in the quality of life of these individuals, and the socioeconomic impact of these patients is significant due to the expenses with the treatments, prolonged and recurrent hospitalizations, physical and social incapacities, with loss of employment and productivity. For the person, there is repercussion in his personal life, affecting his self-image, his self-esteem and his role in the family and in society, and if there is physical limitation, it can lead to social isolation and depression. ${ }^{18,19)}$ Perception of the patient and his family, how to deal with self-care and with the disease. ${ }^{(20)}$ Physical complications occur in the short and long term, with changes in lifestyle, polarization of daily time for treatments, and adverse drug events. ${ }^{(21)}$ Can be compromised as a result of frustration and hopelessness with the disease and its complications; fatigue or dismay with treatment management, as well as low self-esteem, inferiority and depression, ${ }^{(22)}$ which constitute the major challenges for professionals in providing assistance to this clientele.

The limitations of this study were related to obtaining a larger sample due to the difficulty of longitudinal follow up by the clinical involvement of the participants and the maintenance of their adherence to the treatment.

Conclusion. Through the treatment with $\mathrm{BC} / \mathrm{lbu}$ coverage, we obtained promising results such as total healing of 3 wounds, reduction of the area of 9 wounds and debridement of the slough in 5 wounds; reports of absence and/or decreased pain and use of oral analgesics. With the permeation of Ibuprofen, which affects the blood circulation, decreasing or relieving pain, without causing gastrointestinal reactions, it has improved the social life of the patients, as well as the absence of extravasation of the exudate of the wounds, the maintenance of dry dressing and the ease of use of these patient coverage. The coverage of BC/lbu for the vasculogenic wounds such as DF and VU remained intact in the wound bed of the patients; allowed gas exchange and ease of dressing.
For nursing and public health this study is an advance, since it contributes as an alternative in the treatment of chronic wounds, never reported in the literature, of the association between the cellulose membrane and Ibuprofen, since its production and the implementation of its use in users of the public health system with the achievement of promising results.

\section{References}

1. Brito KKG, Sousa MJ, Sousa ATO, Meneses LBA, Oliveira SHS, Soares MJGO. Feridas crônicas: abordagem da enfermagem na produção científica da pós-graduação. Rev. Enferm UFPE Online. 2013; 7(2):414-21.

2. Da Silva PN, De Almeida OAE, Rocha IC. Terapia tópica no tratamento de feridas crônicas. Enferm. Glob. 2014; 33:46-58.

3. Silva MAM, Burihan MC, Barros OC, Nasser F, Ingrund JC, Neser A. Resultados do tratamento da insuficiência venosa crônica grave com espuma de polidocanol guiada por ultrassom. J. Vasc. Bras. 2012; 11(3):206-11.

4. Lima ACB, Guerra DM. Avaliação do custo do tratamento de úlceras por pressão em pacientes hospitalizados usando curativos industrializados. Ciênc. Saúde Colet. 2011;16(1):267-77.

5. Franco D, Gonçalves LF. Feridas cutâneas: a escolha do curativo adequado. Rev. Col. Bras. Cir. 2008; 35(3):203-6.

6. Flores MP, Castro APCR, Nascimento JS. Analgésicos tópicos. Rev. Bras. Anestesiol. 2012; 62(2): 244-52.

7. Jorgensen BO, Friis GJ, Gottrup F. Dor e qualidade de vida para paciente com úlceras de perna de etiologia venosa: prova do conceito de eficácia do Biatain Ibuprofeno ${ }^{\circledR}$ : um novo curativo redutor de dor de feridas. Wound. Repair Regen. 2006; 14:233-9.

8. Macedo EB, Torres GV, Oliveira AA, Medeiros RS, Silva DN, Souza AG. Cost-effectiveness of compression therapy in people with venous ulcers. J. Nurs. UFPE Online. 2013; 7(10):6101-7.

9. Fradique $\mathrm{C}$ et al. Ulcera flebostatica-estudo prospectivo de 202 doentes. Acta Med. Port. $2011 ; 24(1): 71-80$.

10. Dias TYAF, Costa IKF, Melo MDM, Torres SMSGSO, Maia EMC, Torres GV. Avaliação da qualidade de vida de pacientes com e sem úlcera venosa. Rev. Lat. Am. Enfermagem. 2014; 22(4):576-81. 
11. Joaquim FL, Camacho ACLF, Silva RMCRA, Louredo DS, Valente GSC, Santos EC. Reflexão acerca do atendimento domiciliar realizado por enfermeiros no tratamento de úlceras venosas. Rev. Enferm. UFPE Online. 2016; 10(2):664-8.

12. Rossi VEC, Silva AL, Fonseca GSS. Adesão ao tratamento medicamentoso entre pessoas com diabetes mellitus tipo 2. Rev. Enferm. -Oeste Min. 2015; 5(3):1820-30.

13. Comissão Nacional Sobre os Determinantes Sociais da Saúde. Carta aberta aos candidatos à Presidência da República. Rev. Radis [Internet] 2006 [cited 2016 Dez 27]; (49). Available from:

14. http://www6.ensp.fiocruz.br/radis/revistaradis/49/reportagens/comissao-nacional-sobredeterminantes-sociais-da-saude

15. Buss PM, Pelegrini Filho A. A saúde e seus determinantes sociais. Rev. Saúde Colet. 2007; 17(1):77-93.

16. Instituto Brasileiro de Geografia e Estatística. Índice de desenvolvimento humano [Internet]. Araraquara: IBGE; 2010 [cited 2016 Dez 27]. Available from: http://cidades.ibge.gov.br/v3/ cidades/municipio/3503208/pesquisa/37

17. Vieira-Santos ICR, De Souza WV, De Carvalho EF, De Medeiros MCWC, Nóbrega MGL, Lima PMS. Prevalência de pé diabético e fatores associados nas unidades de saúde da família da cidade do
Recife, Pernambuco, Brasil, em 2005. Cad. Saúde Pública. 2008; 24(12):2861-70.

18. Barbosa G, Campos N. Diretrizes para o tratamento da úlcera venosa. Enferm. Glob [Internet]. 2010 [cited 2017 Aug 30];1(20) https://digitum.um.es/ xmlui/bitstream/10201/28791/2/Diretrizes\%20 para \% $200 \% 20$ tratamento $\% 20$ da $\% 20$ $\%$ C3\%BAlcera\%20venosa.pdf

19. Oliveira JC, Taquary SAS, Barbosa AM, Veronezi RJB. Pé diabético e amputações em pessoas internadas em hospital público: estudo transversal. ABCS Health Sci. 2016;41(1):34-9.

20. Coelho MS, Silva DMGV, Padilha MIS. Representações sociais do pé diabético para pessoas com diabetes mellitus tipo 2. Rev. Esc. Enferm. USP. 2009; 43(1):65-71.

21. Salomé GM, Blanes L, Ferreira LM. Assessment of depressive symptoms in people with diabetes mellitus and foot ulcers. Rev. Col. Bras. Cir. 2011; 38(5):327-33.

22. Santos MA, Marques LAS, Cardoso-Oliveira EA, Mastropietro AP, Teixeira CRS, Zanetti ML. Percepção de pacientes com diabetes mellitus tipo 1 sobre o transplante de células-tronco hematopoéticas. Psic.: Teor. e Pesq. 2012; 28(4):425-33.

23. Ramos L, Ferreira EAP. Fatores emocionais, qualidade de vida e adesão ao tratamento em adultos com diabetes tipo 2. Rev. Bras. de Crescimento Desenvol. Hum. 2011; 21(3):867-77. 